ARTICLE

https://doi.org/10.1038/s41467-020-18398-5

\title{
OPEN
}

\section{Potential impacts of mercury released from thawing permafrost}

\author{
Kevin Schaefer (10 ${ }^{1 凶}$, Yasin Elshorbany ${ }^{2}$, Elchin Jafarov ${ }^{3}$, Paul F. Schuster (1) ${ }^{4}$, Robert G. Striegl (1) ${ }^{4}$,
} Kimberly P. Wickland (i) ${ }^{4}$ \& Elsie M. Sunderland (ib ${ }^{5}$

Mercury $(\mathrm{Hg})$ is a naturally occurring element that bonds with organic matter and, when converted to methylmercury, is a potent neurotoxicant. Here we estimate potential future releases of $\mathrm{Hg}$ from thawing permafrost for low and high greenhouse gas emissions scenarios using a mechanistic model. By 2200, the high emissions scenario shows annual permafrost $\mathrm{Hg}$ emissions to the atmosphere comparable to current global anthropogenic emissions. By 2100 , simulated $\mathrm{Hg}$ concentrations in the Yukon River increase by $14 \%$ for the low emissions scenario, but double for the high emissions scenario. Fish $\mathrm{Hg}$ concentrations do not exceed United States Environmental Protection Agency guidelines for the low emissions scenario by 2300, but for the high emissions scenario, fish in the Yukon River exceed EPA guidelines by 2050. Our results indicate minimal impacts to $\mathrm{Hg}$ concentrations in water and fish for the low emissions scenario and high impacts for the high emissions scenario.

\footnotetext{
${ }^{1}$ National Snow and Ice Data Center, Cooperative Institute for Research in Environmental Sciences, University of Colorado Boulder, Boulder, CO, USA. ${ }^{2}$ School of Geoscience, College of Arts and Sciences, University of South Florida, St. Petersburg, FL, USA. ${ }^{3}$ Computational Earth Sciences, Los Alamos National Laboratory, Los Alamos, NM, USA. ${ }^{4}$ U.S. Geological Survey, Water Mission Area, Earth Systems Processes Division, Boulder, CO, USA. ${ }^{5}$ Harvard John A. Paulson School of Engineering and Applied Sciences and Harvard T.H. Chan School of Public Health, Harvard University, Cambridge, MA, USA.

凶email: kevin.schaefer@nsidc.org
} 
$\mathrm{N}$ aturally occurring and anthropogenic $\mathrm{Hg}$ deposits on land from the atmosphere and bonds to receptor sites in plant organic matter ${ }^{1}$. Microbial decay eventually consumes the organic matter ${ }^{2}$, releasing the Hg. Permafrost is soil at or below $0{ }^{\circ} \mathrm{C}$ for at least two consecutive years and the active layer is the surface layer of soil above permafrost that thaws in summer and refreezes in winter. Sedimentation in permafrost regions has buried vegetation over thousands of years, freezing organic matter at the bottom of the active layer into permafrost ${ }^{3}$. Once frozen, microbial decay effectively ceases, locking the accumulated $\mathrm{Hg}$ into the permafrost. Based on soil measurements, permafrost regions store an estimated $1656 \pm 962 \mathrm{Gg} \mathrm{Hg}$ in the top three meters of soil, of which $793 \pm 461 \mathrm{Gg} \mathrm{Hg}$ are frozen in permafrost ${ }^{1}$. Observations indicate accelerated permafrost thaw over the past 30-40 years 4,5 . Model projections estimate a 30-99\% reduction in northern hemisphere permafrost extent by $2100^{6,7}$. When permafrost thaws, microbial decay of the stored organic matter will resume and release $\mathrm{Hg}$, but how much, where, and when remain unclear.

Atmospheric deposition is the dominant source of $\mathrm{Hg}$ to the terrestrial biosphere ${ }^{8,9}$. Because $\mathrm{Hg}$ bonds to organic matter, the terrestrial carbon cycle modulates the terrestrial $\mathrm{Hg}$ cycle. $\mathrm{Hg}$ has three uptake pathways: (1) bonding to soil organic matter, 10,11, (2) stomatal leaf uptake ${ }^{12,13}$, and (3) root absorption ${ }^{12,14}$. Once absorbed by plants, translocation by phloem assimilates $\mathrm{Hg}$ into leaves and wood ${ }^{12,13}$. The deposition of dead leaves, roots, and stems transfers additional $\mathrm{Hg}$ to the soil ${ }^{11,15}$

Hg has four release pathways: (1) evasion into the atmosphere after microbial decay ${ }^{11}$, (2) leaf stomata transpiration ${ }^{14}$, (3) fire ${ }^{11}$, and (4) leaching into groundwater followed by eventual export by rivers into the oceans ${ }^{16}$. Microbial decay frees $\mathrm{Hg}$ from organic matter, but plants and soil organic matter reabsorb ${ }^{11}$ most of this liberated Hg. Whether leaves represent an $\mathrm{Hg}$ source or sink depends on the concentration gradient between the stomata and the atmosphere ${ }^{14}$. Fire consumes soil organic matter, emitting carbon dioxide and $\mathrm{Hg}$ into the atmosphere ${ }^{11}$. Once leached into water, bound to Dissolved Organic Carbon (DOC) and Particulate Organic Carbon (POC), $\mathrm{Hg}$ can methylate, entering the food chain and accumulating in various species, particularly fish ${ }^{8}$.

The biological and physical processes that control the carbon cycle also control the Hg cycle ${ }^{2,9,16}$. We added $\mathrm{Hg}$ to the Simple Biosphere/Carnegie-Ames-Stanford Approach (SiBCASA) terrestrial biogeochemistry model ${ }^{17}$ (Fig. 1, Methods). The model accounts for all uptake pathways of $\mathrm{Hg}$ except leaf stomatal uptake. The model includes soil evasion and leaching $\mathrm{Hg}$ release pathways, but not stomatal transpiration and fire. We ran simulations from 1901 to 2299 using Representative Concentration Pathways 4.5 and 8.5 (hereafter RCP45 and RCP85). RCP45 represents a scenario close to the global target of $2{ }^{\circ} \mathrm{C}$ warming above pre-industrial levels while RCP85 represents a high emissions scenario of unconstrained burning of fossil fuels. We initialize the simulated $\mathrm{Hg}$ to a depth of three meters using observed values ${ }^{1}$ and ran the model for five thousand years to reach steady state where $\mathrm{Hg}$ losses balance gains. In 1901, SiBCASA simulates a total of $1370 \pm 770 \mathrm{Gg} \mathrm{Hg}$ for all soils in permafrost regions, of which $863 \pm 485 \mathrm{Gg} \mathrm{Hg}$ is frozen in permafrost, matching observed values within uncertainty ${ }^{1}$. SiBCASA simulates $507 \pm 284 \mathrm{Gg} \mathrm{Hg}$ in the active layer, which agrees within uncertainty with observed estimates ${ }^{18}$ of $408 \mathrm{Gg} \mathrm{Hg}$. SiBCASA accounts for the fact that microbial decay in frozen soil becomes limited to thin water films around soil particles ${ }^{19}$. Previous models did not account for this, resulting in high microbial decay and low soil $\mathrm{Hg}$ in permafrost regions ${ }^{2}$. Of the $\mathrm{Hg}$ released during microbial decay, we assume $16 \%$ evades into the atmosphere as gaseous elemental $\mathrm{Hg}^{02}, 1.5 \%$ is exported to rivers as the aqueous $\mathrm{Hg}^{\mathrm{II}}$ cation ${ }^{16,20,21}$ and the remaining $\mathrm{Hg}$ is recycled

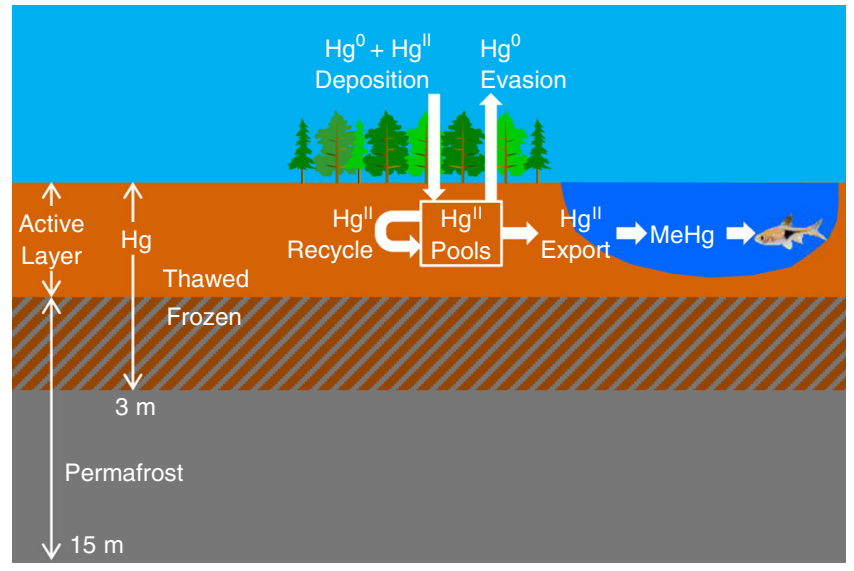

Fig. 1 A schematic of our terrestrial mercury $(\mathbf{H g})$ model. The soil extends down to 15 meters with an active layer that thaws in summer and refreezes in winter. The organic carbon and $\mathrm{Hg}$ extend down to three meters. $\mathrm{Hg}$ deposits onto the surface from the atmosphere and bonds to plant and soil organic matter. As organic matter decays, elemental mercury $\left(\mathrm{Hg}^{0}\right)$ is released into the atmosphere, some mercury cation $\left(\mathrm{Hg}^{\mathrm{Il}}\right)$ is exported into rivers, and the remaining $\mathrm{Hg}^{\mathrm{Il}}$ is recycled back into the organic matter. We use empirical relationships to estimate methyl mercury $(\mathrm{MeHg})$

concentrations in water from $\mathrm{Hg}^{\mathrm{Il}}$ export and total $\mathrm{Hg}$ concentrations in fish from $\mathrm{MeHg}$ concentrations.

back into plants and soil organic matter ${ }^{2}$. Based on observations, we assume $1 \%$ of $\mathrm{Hg}^{\mathrm{II}}$ export methylates into the aqueous monomethyl mercury $(\mathrm{MeHg})^{16}$. We estimate total $\mathrm{Hg}$ concentration in fish by multiplying the simulated $\mathrm{MeHg}$ by an empirical relationship of observed fish concentrations as a function of MeHg concentration in water (Supplementary Fig. 1).

We assume many processes remain constant that will likely change over time and space. For example, we assume constant atmospheric deposition of $\mathrm{Hg}^{0}$ to isolate the thawing permafrost signal, but changing anthropogenic and permafrost emissions will cause this to change over time. We assume constant Yukon River Basin (YRB) discharge, but warming temperatures and thawing permafrost will change the magnitude and timing of the seasonal water flow. We assume constant rates of DOC and POC leaching from soil, constant methylation rates, and steady accumulation of $\mathrm{Hg}$ in fish. However, large-scale permafrost thaw will change local hydrology, likely changing these rates ${ }^{22,23}$

Here, we estimate potential future $\mathrm{Hg}$ releases from thawing permafrost for the circumpolar Arctic and impacts to Hg concentrations in water and fish in the YRB. We leverage a fullphysics model of the terrestrial carbon cycle to simulate potential future changes in the terrestrial $\mathrm{Hg}$ cycle. We predict minimal $\mathrm{Hg}$ releases and small increases in $\mathrm{Hg}$ concentrations in water and fish for a low emissions scenario and large $\mathrm{Hg}$ releases and increases to $\mathrm{Hg}$ concentrations in water and fish for the high emissions scenario.

\section{Results and discussion}

Net Hg flux to the atmosphere. Our simulations indicate thawing permafrost will result in net $\mathrm{Hg}^{0}$ fluxes to the atmosphere from permafrost regions comparable to the current total global anthropogenic emissions by 2200 under RCP $85^{24,25}$ (Fig. 2). The net $\mathrm{Hg}^{0}$ flux is the $\mathrm{Hg}^{0}$ evasion into the atmosphere minus $\mathrm{Hg}^{0}$ deposition from the atmosphere. The net $\mathrm{Hg}^{0}$ fluxes hover around zero during the 1900s, indicating a rough balance between $\mathrm{Hg}^{0}$ deposition and evasion. The permafrost begins to thaw after 1980 (Supplementary Fig. 2) and by 2000 the decay of previously frozen organic matter increases, along with net $\mathrm{Hg}^{0}$ 


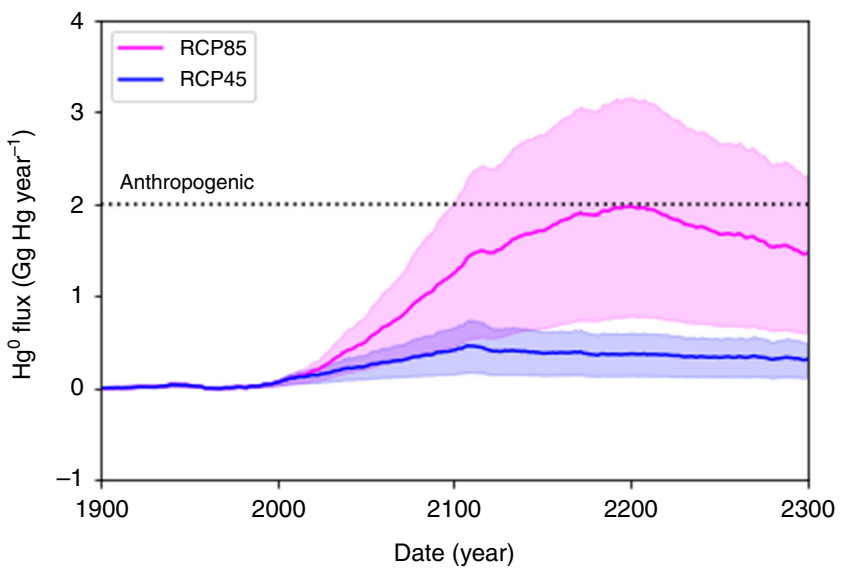

Fig. 2 Annual net elemental mercury $\left(\mathrm{Hg}^{\mathbf{0}}\right)$ flux into the atmosphere. The net flux is $\mathrm{Hg}^{0}$ evasion into the atmosphere minus $\mathrm{Hg}^{\mathrm{O}}$ deposition from the atmosphere, summed across all permafrost regions. The shaded areas represent uncertainty in the net $\mathrm{Hg}^{0}$ flux and the dashed line represents current global anthropogenic emissions.

fluxes. By 2300, 29\% of the permafrost in the top three meters of soil thaws for RCP45 and 84\% of permafrost thaws for RCP85. For $\mathrm{RCP} 45$, the net $\mathrm{Hg}^{0}$ flux increases to $0.5 \pm 0.3 \mathrm{Gg} \mathrm{Hg}$ year ${ }^{-1}$ and permafrost regions become a weak source of $\mathrm{Hg}^{0}$ to the atmosphere. For RCP85, the permafrost regions become a strong source of $\mathrm{Hg}^{0}$ to the atmosphere, peaking at $1.9 \pm 1.1 \mathrm{Gg} \mathrm{Hg}$ year ${ }^{-1}$, comparable to current global anthropogenic emissions ${ }^{8}$ of $\sim 2 \mathrm{Gg}$ $\mathrm{Hg}$ year ${ }^{-1}$. Most of the net $\mathrm{Hg}^{0}$ fluxes result from the decay of old, currently frozen organic matter, so Fig. 2 indicates an injection of pre-industrial $\mathrm{Hg}$ into the modern $\mathrm{Hg}$ cycle. By 2300, we estimate permafrost regions will contribute a cumulative total of $101 \pm$ $57 \mathrm{Gg} \mathrm{Hg}$ for RCP45 and $428 \pm 244 \mathrm{Gg} \mathrm{Hg}$ for RCP85 to the global $\mathrm{Hg}$ cycle (Supplementary Fig. 3).

Our model does not include atmospheric transport, so we cannot predict where and when $\mathrm{Hg}^{0}$ emitted from permafrost regions will redeposit onto the surface. The total, pan-Arctic net $\mathrm{Hg}^{0}$ flux for RCP85 appears consistent in magnitude with global total anthropogenic emissions. However, unlike point sources typical of anthropogenic $\mathrm{Hg}$, we expect to see the net $\mathrm{Hg}^{0}$ flux distributed across the vast Arctic landscape. Although thawed, the organic matter will decay slowly with a characteristic time scale of 75 years due to wet soils and periodic refreezing ${ }^{26}$. Once the permafrost thaws and the decay of organic matter resumes, $\mathrm{Hg}^{0}$ release from permafrost regions will likely persist for centuries.

The vegetation and soil organic matter act as a buffer to slow $\mathrm{Hg}^{0}$ evasion. In our model, $82.5 \%$ of the $\mathrm{Hg}$ released due to microbial decay recycles back into the organic matter. This recycling explains why we see a 30-year lag between the start of large-scale permafrost thaw in the 1990s and the increase in $\mathrm{Hg}^{0}$ evasion after 2020. Continual $\mathrm{Hg}$ deposition onto the surface also partially compensates for losses due to microbial decay. SiBCASA accounts for the northward migration of the tree line and enhanced photosynthesis due to warmer temperatures, longer growing seasons, and higher atmospheric carbon dioxide concentrations. This increased photosynthesis compensates for the loss of soil organic matter in thawed permafrost, resulting in a relatively constant ratio of $\mathrm{Hg}$ to carbon in plants (Supplementary Fig. 4).

Spatial distribution of $\mathbf{H g}$ losses. Projected $\mathrm{Hg}$ losses occur in areas with the greatest thaw and the largest amount of frozen carbon (Fig. 3). For RCP45, permafrost thaw occurred along the entire southern margin of permafrost regions in the

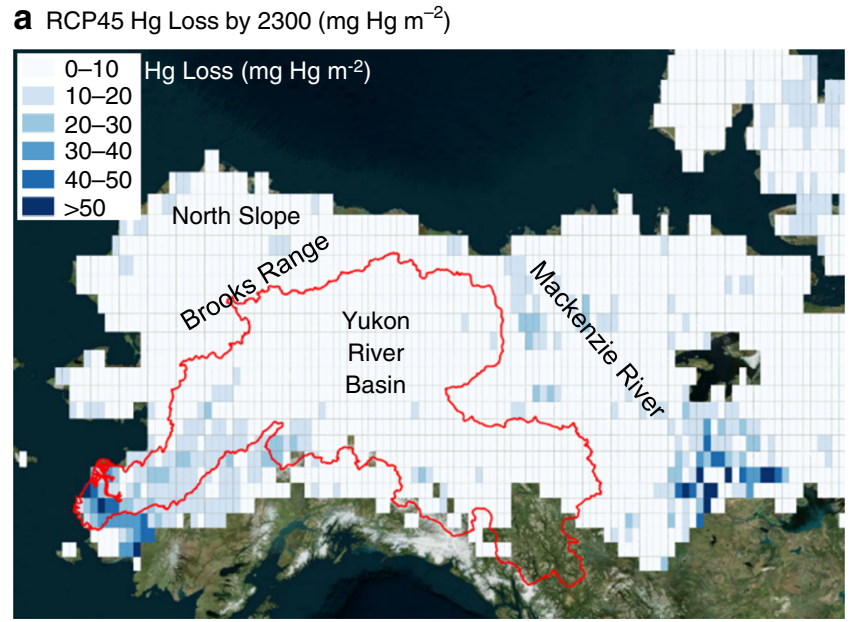

b RCP $85 \mathrm{Hg}$ loss by $2300\left(\mathrm{mg} \mathrm{Hg} \mathrm{m}^{-2}\right)$

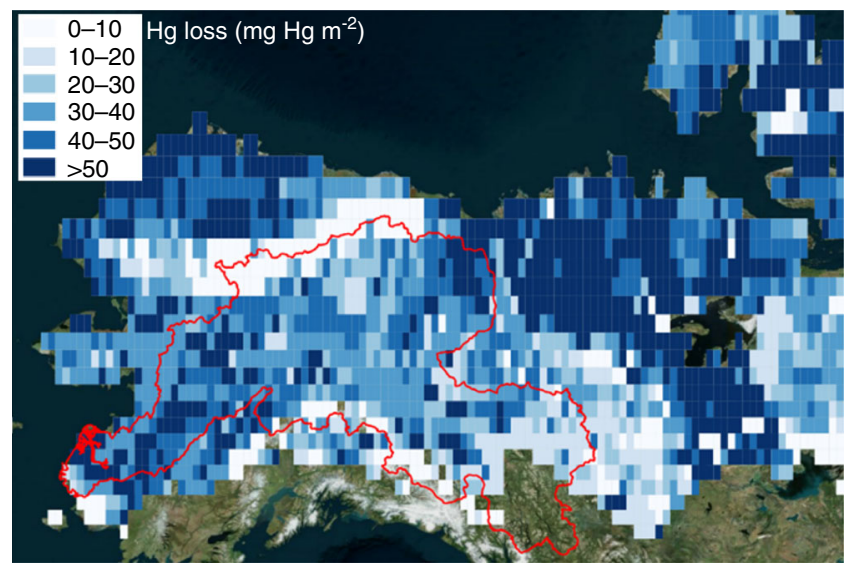

Fig. 3 Cumulative mercury $\mathbf{( H g )}$ loss per area by $\mathbf{2 3 0 0}$. Total $\mathrm{Hg}$ loss is net elemental mercury $\left(\mathrm{Hg}^{0}\right)$ flux to the atmosphere plus mercury cation $\left(\mathrm{Hg}^{\mathrm{I}}\right)$ export by rivers summed from 1901 to 2300. The red outline indicates the spatial extent of the Yukon River Basin.

discontinuous permafrost zone. However, the greatest $\mathrm{Hg}$ losses occur only in thawed areas with large amounts of frozen carbon, specifically the lower YRB near the delta and the upper Mackenzie basin in Canada. This estimate does not account for $\mathrm{Hg}$ losses in areas susceptible to thermokarst or soil collapse during thaw, which our model does not include ${ }^{27}$. RCP85 showed extensive thaw everywhere with small $\mathrm{Hg}$ losses in areas with little frozen carbon, such as the Brooks Range, and the largest $\mathrm{Hg}$ losses in areas with the most frozen carbon, like the North Slope, Alaska. The other major rivers in North America and Eurasia showed the same pattern of $\mathrm{Hg}$ losses in areas of greatest thaw and the largest amount of frozen carbon (Supplementary Fig. 5).

Export of $\mathbf{H g}$ by the Yukon River. The simulated export of aqueous $\mathrm{Hg}$ II in the YRB shows small increases for RCP45 and large increases for RCP85 (Fig. 4, Supplementary Fig. 6). In 2003, the simulated $\mathrm{Hg}^{\mathrm{II}}$ export for the $\mathrm{YRB}$ is $4.8 \pm 2.7 \mathrm{Mg} \mathrm{Hg}$ year $^{-1}$ while the observed export derived from in situ measurements is $4.4 \pm 0.7 \mathrm{Mg} \mathrm{Hg}$ year $^{-1}$, indicating our model matches observations within uncertainty ${ }^{16}$. RCP45 shows relatively small increases in $\mathrm{Hg}^{\mathrm{II}}$ export, consistent with permafrost thaw primarily in the lower Yukon near the delta. In contrast, RCP85 shows permafrost thaw throughout the YRB resulting in a doubling of $\mathrm{Hg}^{\mathrm{II}}$ export by 2100 and a tripling by 2200 . 


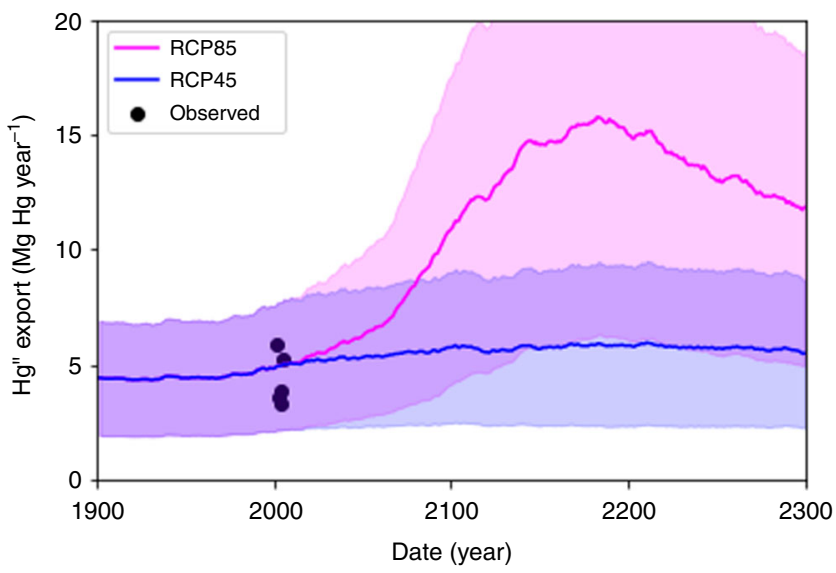

Fig. 4 Mercury cation ( $\mathbf{H g}^{\prime \prime}$ ) export for the Yukon River Basin (YRB). The annual riverine $\mathrm{Hg}^{\|}$export is the sum of $\mathrm{Hg}^{\prime \prime}$ export across the YRB outlined in Fig. 3. The shaded areas represent uncertainty and the black dots indicate observed riverine export ${ }^{16}$.

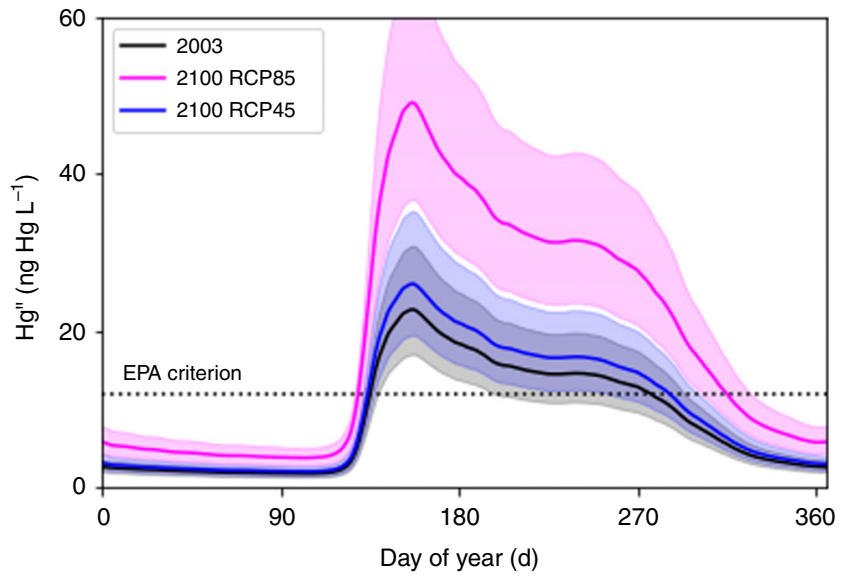

Fig. 5 Mercury cation (Hg'l) concentrations in the Yukon River. We calculated daily $\mathrm{Hg}^{\prime \prime}$ concentrations at Pilot Station, Alaska on the Yukon River. The shaded areas represent uncertainties and the dashed line

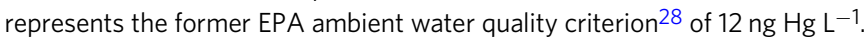

Hg concentrations in the Yukon River. We compared simulated $\mathrm{Hg}$ concentrations in the Yukon River to the United States Environmental Protection Agency (EPA) former ambient water

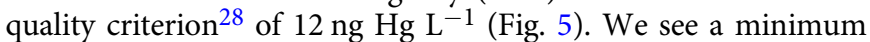
$\mathrm{Hg}^{\mathrm{II}}$ concentration in winter when ice covers the river and a peak in spring when snowmelt increases discharge and $\mathrm{Hg}^{\mathrm{II}}$ export. The $\mathrm{Hg}^{\mathrm{II}}$ concentrations decrease by mid-summer to a relatively constant value and then further decrease in fall when the Yukon River begins to freeze over. In 2003, 85\% of observed $\mathrm{Hg}^{\mathrm{II}}$ concentrations in summer exceeded $12 \mathrm{ng} \mathrm{Hg} \mathrm{L}{ }^{-1}$ while we simulate nearly $100 \%$ exceedance. Nevertheless, the simulated $\mathrm{Hg}$ II concentrations appear consistent with observed values ${ }^{16}$ (Supplementary Fig. 7).

Warming due to climate change will increase $\mathrm{Hg}$ concentrations in the Yukon River, particularly for RCP85 (Fig. 5). We simulate large-scale thawing throughout the YRB along with the appearance of taliks or layers of unfrozen ground where microbial decay and associated $\mathrm{Hg}^{\mathrm{II}}$ export can persist throughout winter. For RCP45, we simulate limited thawing in the YRB. $\mathrm{Hg}^{\mathrm{II}}$ concentrations increase by $14 \%$ in 2100 compared to 2003, a change well within the $30 \%$ uncertainty of simulated values. In contrast, the $\mathrm{Hg}^{\mathrm{II}}$ concentrations for RCP85 increase by $116 \%$ in

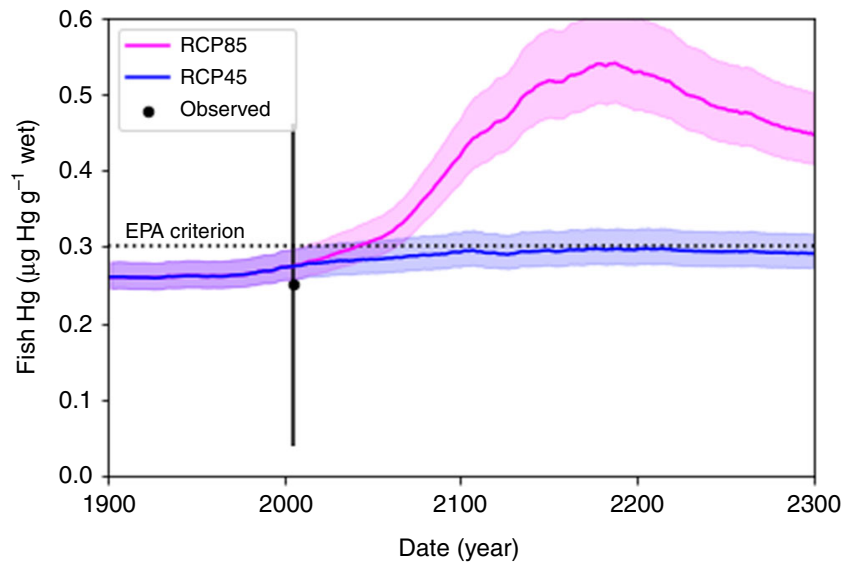

Fig. 6 Mercury $(\mathbf{H g})$ concentration in fish in the Yukon River. The shaded areas represent uncertainty in the simulated values and the dashed line represents the EPA criterion. The dot and vertical error bar shows the median and range of observed concentrations in fish 29,30 .

2100 compared to 2003, more than double 2003 values. For RCP45, the number of days per year that exceed $12 \mathrm{ng} \mathrm{Hg} \mathrm{L}-1$ increase from 132 days to 152 days by 2100 (Supplementary

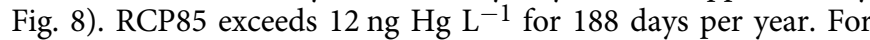
RCP85, Hg concentrations peak around 2160 (not shown), with

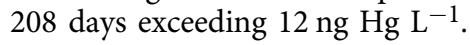

Hg concentration in fish. Large-scale permafrost thaw may increase the concentration of $\mathrm{Hg}$ in fish (Fig. 6). We estimate the concentration of total $\mathrm{Hg}$ in fish $\left(\mathrm{Hg}_{\text {fish }}\right)$ from simulated $\mathrm{MeHg}$ (Supplementary Figs. 1 and 9). The simulated $\mathrm{Hg}_{\text {fish }}$ falls well within the expected range of observed values ${ }^{29,30}$. $\mathrm{Hg}_{\text {fish }}$ varies among fish species and our estimates represent an average for all fish. For RCP45, the average $\mathrm{Hg}_{\text {fish }}$ only increases by $21 \%$ by 2100 due to limited thawing in the YRB. However, for RCP85, $\mathrm{Hg}_{\text {fish }}$ increases by $175 \%$ by 2100 and $222 \%$ by 2300 . The EPA based its criterion of $0.3 \mathrm{~g} \mathrm{Hg} \mathrm{g}^{-1}$ wet weight on the reference dose for $\mathrm{MeHg}$ assuming average consumption rates ${ }^{31,32}$. For RCP45, $\mathrm{Hg}_{\text {fish }}$ does not exceed $0.3 \mathrm{~g} \mathrm{Hg} \mathrm{g}^{-1}$ wet weight, but for RCP85, $\mathrm{Hg}_{\text {fish }}$ exceeds $0.3 \mathrm{~g} \mathrm{Hg} \mathrm{g}^{-1}$ wet weight by 2150 .

Summary. Our results indicate large impacts to $\mathrm{Hg}$ concentrations in water and fish in the YRB for the high emissions scenario and minimal impacts of $\mathrm{Hg}$ contamination for the low emissions scenario. The $\mathrm{Hg}^{0}$ annual, pan-Arctic flux to the atmosphere by 2100 for RCP85 is nearly double that of RCP45 and consistent in magnitude to current anthropogenic fluxes. RCP85 has twice the $\mathrm{Hg}^{\mathrm{II}}$ peak riverine concentration and annual $\mathrm{Hg}^{\mathrm{II}}$ export for the YRB in 2100 compared to RCP45. By 2100, RCP85 exceeds EPA water quality criterion for the entire spring, summer, and fall, while RCP45 shows no significant increase in $\mathrm{Hg}$ concentration in water. Our results indicate a modest or small increase in $\mathrm{Hg}$ concentrations in water and fish in permafrost regions under RCP45. However, for RCP85, the scenario of unconstrained burning of fossil fuels, our results indicate substantial increases in $\mathrm{Hg}$ concentrations in water and fish due to the release of $\mathrm{Hg}$ from thawing permafrost.

\section{Methods}

Model overview. We estimated $\mathrm{Hg}$ releases from permafrost regions using projections of the Simple Biosphere/Carnegie-Ames-Stanford Approach (SiBCASA) model. SiBCASA is a full-physics land surface parameterization with fully coupled carbon, water, and energy cycles ${ }^{17}$. SiBCASA has a full soil model with prognostic soil temperature and moisture with 25 layers extending down to 15 meters. The permafrost dynamics and soil biogeochemistry models account for (1) the effects of 
soil organic matter on soil properties, (2) wind compaction of snow, (3) frozen soil biogeochemistry, (4) a dynamic organic layer, and (5) liquid water content in frozen soils $26,33-36$

Model pool structure. SiBCASA assumes vegetation growth, death, and microbial decay control $\mathrm{Hg}$ uptake and release from the terrestrial ecosystem ${ }^{2}$. We divide the carbon and $\mathrm{Hg}$ into 13 pools representing different vegetation and soil components, such as leaves or humus ${ }^{17}$. The flow of carbon from one pool to the next represents the life cycle of organic matter: photosynthesis produces starch, which plants use to grow leaves, roots, and wood. When the plants die, they produce litter and woody debris, which microbes consume to produce humus. Each time carbon and $\mathrm{Hg}$ transfers from one pool to another, some is lost as respiration of $\mathrm{CO}_{2}$ and evasion of $\mathrm{Hg}^{0}$ to the atmosphere. Each soil layer contains a complete set of carbon and $\mathrm{Hg}$ pools. SiBCASA accounts for the effects of soil temperature and moisture on microbial decay. In frozen soil and permafrost, SiBCASA limits microbial decay to thin water films surrounding soil particles ${ }^{35}$. Here, we report total Hg losses and gains summed over all pools and all layers within the soil column.

Simulated Hg pathways. We assume total atmospheric $\mathrm{Hg}$ deposition consists of $71 \% \mathrm{Hg}^{0}$ and $29 \% \mathrm{Hg}^{\mathrm{II}}$ based on observations ${ }^{9}$. SiBCASA has two uptake pathways, bonding to soil organic matter and root absorption. We assume all Hg gets oxidized to $\mathrm{Hg}^{\mathrm{II}}$ during uptake and evenly distribute the $\mathrm{Hg}^{\mathrm{II}}$ between the two pathways. SiBCASA has two release pathways: aqueous export of $\mathrm{Hg}^{\mathrm{II}}$ by rivers and evasion of $\mathrm{Hg}^{0}$ to the atmosphere after microbial decay. We assume $\mathrm{Hg}^{\mathrm{II}}$ export to rivers results primarily from leaching of Dissolved Organic Carbon (DOC) and Particulate Organic Carbon (POC). We assume a DOC leaching fraction of total respiration of $1.5 \times 10^{-3} \mathrm{~g} \mathrm{C} \mathrm{g} \mathrm{C}^{-1}$ based on laboratory measurements and a POC to DOC ratio of 9:1 to get a total aqueous $\mathrm{Hg}^{\mathrm{II}}$ export fraction of $1.5 \%{ }^{16,20,21}$ or $1.5 \times 10^{-2} \mathrm{~g} \mathrm{Hg}^{\mathrm{II}} \mathrm{g} \mathrm{Hg}^{-1}$. After microbial decay, we assumed an atmospheric $\mathrm{Hg}^{0}$ evasion fraction of $16 \%^{2}$ or $0.16 \mathrm{~g} \mathrm{Hg}^{0} \mathrm{~g} \mathrm{Hg}^{-1}$. The remaining $82.5 \%$ of released $\mathrm{Hg}$ recycles back into the organic matter. We neglect $\mathrm{Hg}$ emissions due to fire and other potential $\mathrm{Hg}$ sources, such as glacial melt and leaching from bedrock.

We estimated $\mathrm{Hg}^{\mathrm{II}}$ export for the Yukon River Basin (YRB) by summing $\mathrm{Hg}^{\mathrm{II}}$ export for all pixels in the YRB and compared the result with observed values of $\mathrm{Hg}^{\mathrm{II}}$ export ${ }^{16}$. We estimated an annual average $\mathrm{Hg}$ concentration in the Yukon River by dividing the annual export by the observed average discharge rate at Pilot Station, Alaska. We assumed daily $\mathrm{Hg}$ concentration is proportional to the discharge rate ${ }^{16}$ and used the median seasonal cycle in observed discharge rates measured at the Pilot Station gaging station ${ }^{37}$. We estimated methyl mercury $(\mathrm{MeHg})$ concentrations using the observed ratio of $1 \%^{16}$ (Supplementary Fig. 9). We estimated fish $\mathrm{Hg}$ concentrations $\left(\mathrm{Hg}_{\text {fish }}\right)$ by multiplying simulated MeHg by a regression of observed $\mathrm{Hg}_{\text {fish }}$ to observed $\mathrm{MeHg}$ (Supplementary Fig. 1).

Uncertainty. We calculated uncertainty in all estimated parameters using Gaussian error propagation. We assumed independent errors and combined them in quadrature. The largest single source of uncertainty comes from the map of soil $\mathrm{Hg}$ used to initialize our model ${ }^{1}$. The next largest source of uncertainty comes from variability in predicted climate, represented as the standard deviation in simulated $\mathrm{Hg}$ fluxes for the five Coupled Model Intercomparison Project (CMIP5) simulations. The spread between models increased over time such that climate uncertainty varied from zero in the modern era to a peak of $37 \%$ after 2200 . We calculated uncertainties for all regressions as the root mean square error (RMSE) of the residuals between the regression model and the original data. The RMSE varied between 5 and $15 \%$ for the various regression coefficients and model parameters, but these did not strongly contribute to overall uncertainty. The largest sources of uncertainty dominate overall uncertainty because we combine them in quadrature using Gaussian error propagation. The overall uncertainty varied from 30 to $60 \%$ and tended to increase over time, reflecting the increased uncertainty in climate. The largest, single source of uncertainty in these projections is the amount of soil $\mathrm{Hg}$ in permafrost regions.

Model simulations. We ran simulations from 1901 to 2299 with a spatial resolution of $0.5 \times 0.5$ degrees latitude and longitude for the permafrost domain using output from five models in the fifth CMIP5 for Representative Concentration Pathways (RCP) 4.5 and 8.5 (RCP45 and RCP85 in the main text). We initialized the Hg pools down to three meters depth with a map of permafrost $\mathrm{Hg}$ based on observations $^{1}$ and spun up the model for 5000 years to steady state initial conditions in 1901 with randomly selected weather years between 1901 and 1910. Steady state initial conditions in 1901 assumes $\mathrm{Hg}^{0}$ and $\mathrm{Hg}^{\mathrm{II}}$ deposition from the atmosphere balances $\mathrm{Hg}^{0}$ evasion and $\mathrm{Hg}^{\mathrm{II}}$ export. The resulting $\mathrm{Hg}$ atmospheric deposition rate of $0.75 \mathrm{Gg} \mathrm{Hg}_{\text {year }}{ }^{-1}$ or $0.9 \mathrm{ng} \mathrm{Hg} \mathrm{m}^{-2} \mathrm{~h}^{-1}$ appears consistent with observed values of $1.4 \pm 1.0 \mathrm{ng} \mathrm{Hg} \mathrm{m}^{-2} \mathrm{~h}^{-1}$ on the North Slope of Alaska ${ }^{9}$. The simulations start at steady state in 1901, but after 1901 the pools and simulated flux drift in response to climate. The magnitude and range of simulated $\mathrm{Hg}^{0}$ flux and $\mathrm{Hg}^{\mathrm{II}}$ export appear consistent with observed values ${ }^{38}$ (Supplementary Figs. 10, 11, and 12).

\section{Data availability}

This article includes all data generated or used during this study in its Supplementary Dataset files.

Received: 18 June 2019; Accepted: 12 August 2020; Published online: 16 September 2020

\section{References}

1. Schuster, P. F. et al. Permafrost stores a globally significant amount of mercury. Geophys. Res. Lett. 45, 1463-1471 (2018).

2. Smith-Downey, N. V., Sunderland, E. M. \& Jacob, D. J. Anthropogenic impacts on global storage and emissions of mercury from terrestrial soils: Insights from a new global model. J. Geophys. Res. 115, G03008 (2010).

3. Zimov, S. A. et al. Permafrost carbon: Stock and decomposability of a globally significant carbon pool. Geophys. Res. Lett. 33, https://doi.org/10.1029/ 2006GL027484 (2006)

4. Romanovsky, V., Grosse, G. \& Marchenko, S. Past, present and future of permafrost in a changing world. Geo. Soc. Am. 40, 397 (2008).

5. Biskaborn et al. Permafrost is warming at a global scale. Nat. Comm. 10, 264 (2019).

6. Koven, C. D., Riley, W. J. \& Stern, A. Analysis of permafrost thermal dynamics and response to climate change in the CMIP5 Earth System Models. J. Clim. V26, 1887-1900 (2013).

7. McGuire, A. D. et al. Dependence of the evolution of carbon dynamics in the northern permafrost region on the trajectory of climate change. Proc. Natl Acad. Sci. USA 115/15, 3882-3887 (2018).

8. Driscoll, C. T., Mason, R. P., Chan, H. M., Jacob, D. J. \& Pirrone, N. Mercury as a global pollutant: sources, pathways, and effects. Environ. Sci. Technol. 47, 4967-4983 (2013)

9. Obrist, D. et al. Tundra uptake of atmospheric elemental mercury drives Arctic mercury pollution. Nature 547, 201-204 (2017).

10. Skyllberg, U., Bloom, P. R., Qian, J., Lin, C. M. \& Bleam, W. F. Complexation of mercury(II) in soil organic matter: EXAFS evidence for linear twocoordination with reduced sulfur groups. Environ. Sci. Technol. 40, 4174-4180 (2006).

11. Giesler, R., Clemmensen, K. E., Wardle, D. A., Klaminder, J. \& Bindler, R. Boreal forests sequester large amounts of mercury over millennial time scales in the absence of wildfire. Environ. Sci. Technol. 51, 2621-2627 (2017).

12. Arnold, J., Gustin, M. S. \& Weisberg, P. J. Evidence for nonstomatal uptake of $\mathrm{Hg}$ by Aspen and translocation of $\mathrm{Hg}$ from foliage to tree rings in Austrian pine. Environ. Sci. Technol. 52, 1174-1182 (2018).

13. Clackett, S. P., Porter, T. J. \& Lehnherr, I. 400-year record of atmospheric mercury from tree-rings in Northwestern Canada. Environ. Sci. Technol. 52, 9625-9633 (2018).

14. Lindberg, S. E., Hanson, P. J., Meyers, T. P. \& Kim, K. H. Air/surface exchange of mercury vapor over forests - the need for a reassessment of continental biogenic emissions. Atm. Environ. 32, 895-908 (1998).

15. Jiskra, M. et al. Mercury deposition and re-emission pathways in boreal forest soils investigated with $\mathrm{Hg}$ isotope signatures. Environ. Sci. Technol. 49, 7188-7196 (2015).

16. Schuster, P. F. et al. Mercury export from the Yukon River Basin and potential response to a changing climate. Environ. Sci. Technol. 45, 9262-9267 (2011).

17. Schaefer, K. et al. Combined Simple Biosphere/Carnegie-Ames-Stanford Approach terrestrial carbon cycle model. J. Geophys. Res. 113, G03034 (2008).

18. Olson, C., Jiskra, M., Biester, H., Chow, J. \& Obrist, D. Mercury in active-layer Tundra soils of Alaska: concentrations, pools, origins, and spatial distribution. Glob. Biogeochemical Cycles 32, 1058-1073 (2018).

19. Mikan, C. J., Schimel, J. P. \& Doyle, A. P. Temperature controls of microbial respiration in arctic tundra soils above and below freezing. Soil Biol. Biochem. 34, 1785-1795 (2002).

20. Wang, Z. \& Roulet, N. Comparison of plant litter and peat decomposition changes with permafrost thaw in a subarctic peatland. Plant Soil 417, 197-216 (2017).

21. Wickland, K. P. et al. Dissolved organic carbon and nitrogen release from boreal Holocene permafrost and seasonally frozen soils of Alaska. Environ. Res. Lett. 13, 065011 (2018).

22. Striegl, R. G., Aiken, G. R., Dornblaser, M. M., Raymond, P. A. \& Wickland, K. P. A decrease in discharge-normalized DOC export by the Yukon River during summer through autumn. Geophys. Res. Lett. 32, L21413 (2005).

23. Walvoord, M. A. \& Striegl, R. G. Increased groundwater to stream discharge from permafrost thawing in the Yukon River basin: potential impacts on lateral export of carbon and nitrogen. Geophys. Res. Lett. 34, L12402 (2007).

24. Holmes, C. D. et al. Global atmospheric model for mercury including oxidation by bromine atoms. Atmos. Chem. Phys. 10, 12037-12057 (2010). 
25. Pacyna, J. M. et al. Current and future levels of mercury atmospheric pollution on a global scale. Atmos. Chem. Phys. 16, 12495-12511 (2016).

26. Schaefer, K., Zhang, T., Bruhwiler, L. \& Barrett, A. P. Amount and timing of permafrost carbon release in response to climate warming. Tellus Series $B$ Chem. Phys. Met. https://doi.org/10.1111/j1600-0889201100527x (2011).

27. St Pierre, K. A. et al. Unprecedented increases in total and methyl mercury concentrations downstream of retrogressive thaw slumps in the western Canadian arctic. Environ. Sci. Technol. 52, 14099-14109 (2018).

28. EPA. Ambient water quality criteria for mercury. U.S. Environmental Protection Agency, 440/5-84-026 (https://www.epa.gov/sites/production/files/ 2019-03/documents/ambient-wqc-mercury-1984.pdf) (1984).

29. Brumbaugh, W. G., Krabbenhoft, D. P., Helsel, D. R., Wiener, J. G., \& Echols, K. R. A national pilot study of mercury contamination of aquatic ecosystems along multiple gradients: bioaccumulation in fish, Biological Science Report. USGS/BRD/BSR-2001-0009 (2001).

30. Scudder, E. et al. Optimizing fish sampling for fish-mercury bioaccumulation factors. Chemosphere 135, 467-473 (2015).

31. National Research Council. Toxicological effects of methylmercury. https://doi. org/10.17226/9899 (The National Academies Press, Washington, DC, 2000).

32. Borum, D., Manibusan, M. K., Schoeny, R., Winchester, E. L. Water quality criterion for the protection of human health: methylmercury. EPA-823-R-01001 (U.S. Environmental Protection Agency, Washington, DC 20460, 2001).

33. Schaefer, K. et al. Improving simulated soil temperatures and soil freeze/thaw at high-latitude regions in the Simple Biosphere/Carnegie-Ames-Stanford Approach model. J. Geophys. Res. 114, F02021 (2009).

34. Schaefer, K., Lantuit, H., Romanovsky, V. E., Schuur, E. A. G. \& Witt, R. The impact of the permafrost carbon feedback on global climate. Env. Res. Lett. 9, 085003 (2014).

35. Schaefer, K. \& Jafarov, E. A parameterization of respiration in frozen soils based on substrate availability. Biogeosciences 13, 1991-2001. www. biogeosciences.net/13/1991/2016/ (2016).

36. Jafarov, E. \& Schaefer, K. The importance of a surface organic layer in simulating permafrost thermal and carbon dynamics. Cryosphere 10, 465-475 (2016).

37. USGS, United States Geological Survey. Data inventory page for site 15565447-Yukon River at Pilot Station, Alaska. U.S. Geological Survey, https://waterdata.usgs.gov/nwis/inventory/site_no $=15565447$ (2019).

38. Agnan, Y., Le Dantec, T., Moore, C. W., Edwards, G. C. \& Obrist, D. New constraints on terrestrial surface atmosphere fluxes of gaseous elemental mercury using a global database. Environ. Sci. Technol. 50, 507-524 (2016).

\section{Acknowledgements}

We thank Richard Webb for valuable help and technical advice. Funding came from the NASA grants NNX10AR63G, NNX06AE65G, NNX13AM25G, and NNX17AC59A;

NOAA grant NA09OAR4310063; and NSF grants ARC 10901962, 1204167, and
1553171 and AGS 1900795. Funding came from the Next-Generation Ecosystem Experiments (NGEE Arctic) project, supported by the Office of Biological and Environmental Research in the U.S. DOE Office of Science. The use of any trade, product, or firm names is for descriptive purposes only and does not imply endorsement by the U.S Government.

\section{Author contributions}

K.S. wrote the paper and modified SiBCASA to include Hg. Y.E. and E.J. made the required model simulations. P.F.S. developed the original concept and collected most of the data used to parameterize the model. R.G.S. and K.P.W. provided analysis and measurements for model evaluation. E.M.S. provided analysis related to EPA criterion.

\section{Competing interests}

The authors declare no competing interests.

\section{Additional information}

Supplementary information is available for this paper at https://doi.org/10.1038/s41467020-18398-5.

Correspondence and requests for materials should be addressed to K.S.

Peer review information Nature Communications thanks the anonymous reviewers for their contributions to the peer review of this work.

Reprints and permission information is available at http://www.nature.com/reprints

Publisher's note Springer Nature remains neutral with regard to jurisdictional claims in published maps and institutional affiliations.

\begin{abstract}
Open Access This article is licensed under a Creative Commons Attribution 4.0 International License, which permits use, sharing,
adaptation, distribution and reproduction in any medium or format, as long as you give appropriate credit to the original author(s) and the source, provide a link to the Creative Commons license, and indicate if changes were made. The images or other third party material in this article are included in the article's Creative Commons license, unless indicated otherwise in a credit line to the material. If material is not included in the article's Creative Commons license and your intended use is not permitted by statutory regulation or exceeds the permitted use, you will need to obtain permission directly from the copyright holder. To view a copy of this license, visit http://creativecommons.org/ licenses/by/4.0/.
\end{abstract}

(C) The Author(s) 2020 